\title{
Fatty Acid Profile and Physico-Chemical Parameters of Castor Oils in Tanzania
}

\author{
Athumani Omari1, Quintino A. Mgani², Egid B. Mubofu2* \\ ${ }^{1}$ Department of General Studies, Arusha Technical College, Arusha, Tanzania \\ ${ }^{2}$ Chemistry Department, University of Dar es Salaam, Dar es Salaam, Tanzania \\ Email: "ebmubofu@gmail.com
}

Received 15 June 2015; accepted 14 November 2015; published 17 November 2015

Copyright (C) 2015 by authors and Scientific Research Publishing Inc.

This work is licensed under the Creative Commons Attribution International License (CC BY).

http://creativecommons.org/licenses/by/4.0/

(c) (i) Open Access

\begin{abstract}
This paper reports on the assessment of the quality and quantity of castor oil from castor seeds collected from different regions in Tanzania. The castor seeds from Arusha, Dar es Salaam, Dodoma, Iringa, Kagera and Morogoro regions in Tanzania were extracted by Soxhlet method using $n$-hexane and the oil yields were determined. The yields were $52.78 \%, 49.95 \%, 47.89 \%, 44.23 \%$, 43.71\% and 43.69\% for Dodoma, Arusha, Iringa, Morogoro, Kagera and Dar es Salaam respectively. The physico-chemical parameters that were determined were refractive index (1.468 - 1.473), $\mathrm{pH}$ 5.7- 6.3, viscosity (0.943 - 0.954), specific gravity (165.50 - $187.46 \mathrm{mg} \mathrm{KOH/g} \mathrm{Oil),} \mathrm{saponification}$ value (76.68 - $80 \mathrm{mg} \mathrm{KOH} / \mathrm{g}$ Oil), iodine value (76.68 - $80.12 \mathrm{~g} \mathrm{I}_{2} / 100 \mathrm{~g}$ Oil), acid value (0.44 - 1.97 $\mathrm{mg} \mathrm{NaOH} / \mathrm{g} \mathrm{Oil)}$, free fatty acid $(0.22-0.99)$ and peroxide value $(10.79-13.73)$. Fatty acid profile of castor oil was analysed using Shimadzu GCMS and ricinoleic acid ranged from $83.5 \%$ to $92.3 \%$ of the total fatty acids in the castor oils.
\end{abstract}

\section{Keywords}

Castor Oil, Fatty Acid Profile, Characterization

\section{Introduction}

Castor plant is cultivated and grows in the wild throughout the tropical, warm temperate and subtropical regions between latitudes $40^{\circ}$ South and $52^{\circ}$ North. In Tanzania, castor plant, Ricinus communis grows as a wild plant almost all over the country [1]. The plant mostly occurs at altitudes ranging from sea level to about $3000 \mathrm{~m}$ [2].

Castor oil is a pale yellow viscous liquid with mild odour and boils at $313^{\circ} \mathrm{C}\left(595^{\circ} \mathrm{F}\right)$. It has a density and molecular weight of $961 \mathrm{~kg} / \mathrm{m}^{3}\left(0.961 \mathrm{~g} / \mathrm{cm}^{3}\right)$ and $933 \mathrm{~g} / \mathrm{mol}$ respectively and is normally obtained by solvents extraction or mechanical pressing of dried castor seeds. The high content of ricinoleic acid with its three functional

*Corresponding author. 
groups of hydroxyl, carboxylate and carbon-carbon double bond (alkene) is the main reason why castor oil has versatile application possibilities in the chemical industry [3]-[5]. It has been noted that castor oils differ depending on the geographical location in which the plant is grown and the agricultural modifications which have been made during growth [6].

Relative to other vegetable oils, castor oil has different physical and chemical properties which vary with the method of extraction (solvent or mechanical pressing) of the oil. The castor oil that is obtained from the cold pressing method has low acid value, low iodine value, lighter color and slightly higher saponification value compared to the solvent-extracted oil [5]). Overall, triglycerides of 12-hydroxy-9-octadecenoic acid (ricinoleic acid) are the major component of castor oil and are normally over $89 \%$ of the total fatty acid of the oil. The structures and the percentages of other fatty acids found in the castor oil are linoleic (4.2\%), oleic (3.0\%), stearic (1\%), palmitic (1\%), dihydroxystearic acid (0.7\%), linolenic acid (0.3\%), and eicosanoic acid (0.3\%) [7] [8]). The chemistry of castor oil can be focused on its high content of ricinoleic acid which has three functional groups.

Castor oil is used to make soap, sulfated castor oil or Turkey Red Oil which is used to manufacture detergent, and other forms of the oil are important for the treatment of leather, industrial lubricants, and other industrial uses [9]. Castor oil is also regarded as one of the most valuable laxatives in medicine [8]. Other novel uses of castor oil and its derivatives include nylon-6,10 from sebacic acid, nylon-11 from 11-aminoundecanoic acid. This study therefore aimed at assessing the quantity, quality and characterization of castor oil collected from six different regions in Tanzanian.

\section{Materials and Methods}

\subsection{Castor Seeds Collection}

The castor seeds were collected from the outskirt of Arusha, Kagera, Iringa, Dar es Salaam, Dodoma and Morogoro regions. These regions have vast geographical diversity. While the temperature in Arusha typically ranges between $5^{\circ} \mathrm{C}$ and $30^{\circ} \mathrm{C}$ and receives an average precipitation of about $87.7 \mathrm{~mm}$ per annum, the average temperature in Dar es salaam is $30^{\circ} \mathrm{C}$ and an average precipitation of $95.4 \mathrm{~mm}$. Morogoro has an average temperature is $30.1^{\circ} \mathrm{C}$ and an average precipitation of $77.9 \mathrm{~mm}$, Iringa average temperature is $24.8^{\circ} \mathrm{C}$ and an average precipitation of $55.1 \mathrm{~mm}$, Dodoma an average temperature is $29^{\circ} \mathrm{C}$ and an average precipitation of $39.1 \mathrm{~mm}$, Kagera average temperature is $26.3^{\circ} \mathrm{C}$ and an average precipitation of $175.1 \mathrm{~mm}$ [10]. The seeds collected were of different sizes, colour and shapes ranging from $11 \mathrm{~mm}$ to $18 \mathrm{~mm}$. All chemicals were analytical grade from Sigma Aldrich and Merck and were used without any further purification.

\subsection{Determination of Moisture Content of the Seeds}

About $20 \mathrm{~g}$ of a clean sample was weighed and then dried in the oven at $80^{\circ} \mathrm{C}$ for $7 \mathrm{hrs}$ and the weight was recorded after every 2 hrs. The same procedure was repeated until a constant weight was obtained. After 2 hours, the sample was removed from the oven and placed in the dessicator for 30 minutes to cool then removed and re-weighed. The percentage moisture content in the seeds was calculated from the expression:

$$
\% \text { moisture }=\frac{W 1-W 2}{W 1} \times 100
$$

where $W 1$ = original weight of the sample before drying; $W 2$ = weight of the sample after drying.

\subsection{Extraction of Castor Oil}

In a typical extraction experiment, about $200 \mathrm{~mL} n$-hexane was measured and then poured into a round bottom flask. A sample weighing $10 \mathrm{~g}$ was placed in the thimble and then inserted in the centre of the extractor. The solvent was heated to $70^{\circ} \mathrm{C}$ and when the solvent boiled, the vapour rose through the vertical tube into the condenser at the top. The liquid condensate dripped into the filter paper thimble in the centre which contained the solid sample to be extracted. The extract seeped through the pores of the thimble and filled the siphon tube, where it flowed back down into the round bottom flask. This was allowed to continue for $3 \mathrm{~h}$ so as to maximize the oil yield. The experiment was repeated by placing $10 \mathrm{~g}$ of the sample into the thimble again [11]. 


\subsection{Determination of the Percentage of Castor Oil Extracted}

The sample to be extracted, $10 \mathrm{~g}$ was placed in the thimble and $200 \mathrm{~mL}$ of $n$-hexane poured into the empty round bottom flask. The solvent was heated to $70^{\circ} \mathrm{C}$ and allowed to heat for $3 \mathrm{~h}$ continuously while extracting the oil by using Soxhlet apparatus. Different weight of the sample, $10 \mathrm{~g}, 15 \mathrm{~g}$ and $20 \mathrm{~g}$ were added in the apparatus at $3 \mathrm{~h}$ intervals, solvent was evaporated using rotary evaporator and the percentage of oil determined using known procedures [12].

\subsection{Determination of Percentage Composition of Fatty Acid in Castor Oil}

The percentage composition of fatty acids in the castor oil was determined by the Shimadzu Gas Chromatograph-Mass Spectrometer (GCMS-QP 2010 Plus) at the chemistry department using standard Fatty Acid Methyl Esters (FAMEs) [11]. The retention time and peak height/area were used in qualitative and quantitative determination of the castor oil components.

Fatty acid methyl esters (FAME's) for GC-MS analysis were prepared and the fatty acid composition of castor oil was determined by GCMS-QP 2010 plus, Shimadzu Japan equipped with HP capillary column and helium carrier gas. The column temperature was programmed at $120^{\circ} \mathrm{C}$ with an increment of $3^{\circ} \mathrm{C}$ per minute for 57 minutes whereas the injector and detector temperatures were set at $260^{\circ} \mathrm{C}$ and $280^{\circ} \mathrm{C}$, respectively as reported elsewhere [8].

\subsection{Determination of Physical Parameters}

The physical properties of the liquids depend on their chemical composition, pressure and temperature. An unknown oil physical parameter can be measured and compared with the literature and standard values, the oil can then be identified.

\subsubsection{Specific Gravity}

Density bottle was used in determining the specific gravity of the oil. A clean and dry stoppered bottle of $25 \mathrm{~mL}$ capacity was weighed (W0) and then filled with the oil stoppered and reweighed to give (W1). The oil was substituted with distilled water after washing and drying the bottle and weighed to give (W2). The expression for specific gravity (Sp.gr) is:

$$
\text { Sp.gr }=\frac{W 1-W 2}{W 2-W 0}
$$

where $W 0$ = weight of dry empty density bottle; $W 1=$ weight of density bottle + oil; $W 2$ = weight of density bottle + distilled water [9] [13].

\subsubsection{Viscosity}

A clean, dried Ostwald viscometer with a flow time above 200 seconds for the fluid to be tested was elected. The sample was filtered through a sintered glass (fine mesh screen) to eliminate dust and other solid materials in the liquid sample. The viscosity meter was charged with the sample by inverting the tube's thinner arm into the liquid sample and suction force drawn up to the upper timing mark of the viscometer, after which the instrument was turned to its normal vertical position. The viscometer was placed into a holder and inserted to a constant temperature bath set at $29^{\circ} \mathrm{C}$. The oil was kept for approximately 10 minutes for it to come to the bath temperature of $29^{\circ} \mathrm{C}$. The suction force was then applied to the thinner arm to draw the sample slightly above the upper timing mark. The afflux time was recorded by timing the flow of the sample as it flowed freely from the upper timing mark to the lower timing mark [14]. Three recordings were taken and using water as a standard, a viscosity for each sample was recorded.

\subsubsection{Refractive Index}

Abbe's refractometer was used in the determination of refractive index. This instrument measures the index of refraction by measuring the critical angle of total reflection. In this case, a few drops of the sample were transferred into the glass slide of the refractometer. Water at $30^{\circ} \mathrm{C}$ was circulated round the glass slide to keep its temperature uniform. Through the eyepiece of the refractometer, the dark portion viewed was adjusted to be in 
line with the intersection of the cross. At no parallax error, the pointer on the scale pointed to the refractive index. The refractometer was calibrated using distilled water where the refractive index of water at that temperature was obtained [14]. The procedure was repeated by using castor oil from the six regions and their refractive indices were obtained at $30^{\circ} \mathrm{C}$. The mean value for each region was noted and recorded as the refractive index.

\subsection{4. $\mathrm{pH}$}

In a dry clean $25 \mathrm{~mL}$ beaker, $2 \mathrm{~g}$ of the sample was placed followed by $13 \mathrm{~mL}$ of hot distilled water and the mixture was stirred slowly. The mixture was then cooled in a cold-water bath to $25^{\circ} \mathrm{C}$. The $\mathrm{pH}$ electrode was standardized with buffer solutions (pH 4 and 7) and the electrode immersed into the sample where an average $\mathrm{pH}$ of three recordings per sample were recorded [9].

\subsection{Determination of Chemical Parameters}

\subsubsection{Acid Value}

Into a dried $250 \mathrm{~mL}$ conical flask was placed $5.0 \mathrm{~g}$ of the oil sample followed by $25 \mathrm{~mL}$ of absolute ethanol and 3 drops of phenolphthalein indicator. The mixture was heated in a shaking water bath for 5 minutes. While hot, it was titrated against $0.1 \mathrm{~N} \mathrm{KOH}$ until pink color appeared. Vigorous shaking was done when approaching the end point to ensure thorough mixing. The volume of $0.1 \mathrm{~N} \mathrm{KOH}$ consumed by an acid was recorded. The acid value was calculated as reported in the literature [15].

$$
\text { A.V }=\frac{56.1 \times V \times N}{m}
$$

where $V=$ volume of $\mathrm{KOH}$ used; $N=$ normality of $\mathrm{KOH}$ and $m=$ mass of sample.

\subsubsection{Iodine Value}

To $0.25 \mathrm{~g}$ of the oil sample in a $250 \mathrm{~mL}$ conical flask was added $10 \mathrm{~mL}$ of chloroform followed by $30 \mathrm{~mL}$ of Hanus iodine solution. The flask was securely closed and the solution was left shaking for 30 minutes in the dark. This was followed by adding $10 \mathrm{~mL}$ of $15 \%$ potassium iodide solution and then shaken, after which 100 $\mathrm{mL}$ of distilled water was added. The mixture was then titrated with the iodine solution against $0.1 \mathrm{~N}$ Sodium thiosulfate solution till a yellow color formed. This was followed by addition of 2 - 3 drops of starch solution after which a blue solution formed. The titration continued until the blue color disappeared while the volume of $\mathrm{Na}_{2} \mathrm{~S}_{2} \mathrm{O}_{3}$ at end point was recorded. The Iodine value (I.V) was calculated as reported by other workers [16].

$$
\mathrm{I} . \mathrm{V}=\frac{12.69 \times c \times(V 1-V 2)}{m}
$$

where $c$ = Concentration of $\mathrm{Na}_{2} \mathrm{~S}_{2} \mathrm{O}_{3}$ used; $V 1=$ vol of $\mathrm{Na}_{2} \mathrm{~S}_{2} \mathrm{O}_{3}$ used for the blank; $V 2=$ vol of $\mathrm{Na}_{2} \mathrm{~S}_{2} \mathrm{O}_{3}$ used for sample; $m=$ mass of the sample.

\subsubsection{Saponification Value}

A one gram $(1 \mathrm{~g})$ sample of the oil was weighed into a $250 \mathrm{~mL}$ glass conical flask, and then $10 \mathrm{~mL}$ of ethanolether mixture (2:1) was added to the same flask followed by $25 \mathrm{~mL}$ of $0.5 \mathrm{~N}$ ethanolic potassium hydroxide. The flask was then fitted to a reflux condenser and refluxed using a boiling water bath for $30 \mathrm{~min}$ with occasional shaking. To the warm solution were added 3 - 4 drops of phenolphthalein indicator and the warm solution was titrated against $0.5 \mathrm{M} \mathrm{HCl}$ to the end point. The same procedure was used for other samples and blank. The expression for saponification value (S.V) is given by equation [15]:

$$
\mathrm{S} . \mathrm{V}=\frac{56.1 \times N \times(B-S)}{m}
$$

where $B$ = the volume of the solution used for blank test; $S=$ the volume of the solution used for determination; $N=$ Actual normality of the HCl used; $m=$ Mass of the sample.

\subsubsection{Peroxide Value}

Into a $250 \mathrm{~mL}$ Erlenmeyer flask, $1 \mathrm{~g}$ of the oil sample, $1 \mathrm{~g}$ of potassium iodide and $20 \mathrm{~mL}$ of solvent mixture 
(glacial acetic acid/chloroform, 3/2 by volume) were added and the mixture was boiled for one minute. The hot solution was poured into a flask containing $20 \mathrm{~mL}$ of $5 \%$ potassium iodide. Thereafter, 3 drops of starch solution were added to the mixture and the latter was titrated with $0.025 \mathrm{~N}$ standardized sodium thiosulphate and the peroxide value was determined following the method reported by Kyari [17] using the equation:

$$
\text { P.V }=\frac{S \times N \times 100}{w}
$$

where, $S=\mathrm{mL}$ of $\mathrm{Na}_{2} \mathrm{~S}_{2} \mathrm{O}_{3} ; N=$ normality of $\mathrm{Na}_{2} \mathrm{~S}_{2} \mathrm{O}_{3} ; W=$ weight of oil sample (g).

\section{Results and Discussion}

\subsection{Moisture Content of the Castor Seeds}

The percentage of moisture content of the castor seeds were summarized in Table 1. As shown in Figure 1, the castor seeds collected from different regions had different moisture content owing to their differences in place of origin, seed variety, time of harvesting and storage time. It was necessary to determine the moisture content of the Tanzanian castor seeds since it shows how much water should be removed by drying before they are subjected for Soxhlet oil extraction. Furthermore it tells us on the storage time (shelf life) the seeds can stay without encouraging microbial activity such as fungus. Figure 1 showed that Dar es Salaam had the highest seed moisture content (5.4\%) as compared to other regions possibly because they were collected shortly before the extraction was done and hence had a very short storage time. Kagera has the lowest seed moisture content of $1.83 \%$ as compared to other regions due to the long stay after their collection. Other results agreed well with the literature values where moisture contents of $0.2 \%$ and $4.12 \%$ are reported elsewhere. [9] [8]. Too much water in seeds makes the castor seeds vulnerable to hydrolysis by lipase enzyme. The actions of microbes and lipase reduces the quality of castor oil produced since their activity results in the production of free fatty acid which eventually elevates the level of acid value making the oil unfit for biodiesel and other uses or requires more time and resources for neutralization.

\subsection{Percentage of Castor Oil Extracted}

These values (Figure 2) were generally higher than yields obtained in some literature [9] [17] which were 29.11\% and 33.2\% respectively. However, the values are similar to results reported by other workers [8] [18]. Dodoma had the highest oil yield probably because of the type of soil and the climate as it receives minimal amount of rainfall and has a favourable ambient temperature ranging from $28^{\circ} \mathrm{C}$ to $34^{\circ} \mathrm{C}$ and very low humidity. Castor plant needs a temperature between $20^{\circ} \mathrm{C}$ and $30^{\circ} \mathrm{C}$ with low humidity throughout the growing season in order to give maximum yield [7] and hence the high yield in Dodoma. Dar es Salaam had the lowest oil content of about $43 \%$. This can be attributed to the acidity of Dar es Salaam soils caused by too much emission of $\mathrm{CO}_{2}$ and

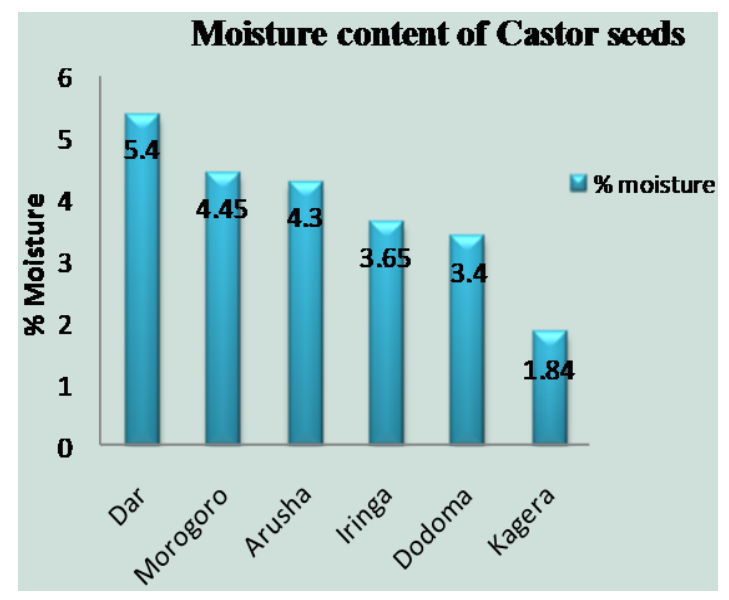

Figure 1. Determination of moisture content of castor seeds. 


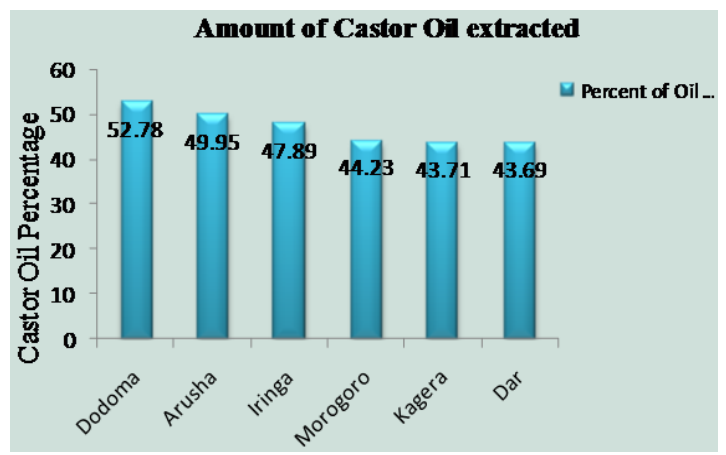

Figure 2. Determination of \% oil extracted.

Table 1. Castor oil fatty acid profiles from Tanzania.

\begin{tabular}{ccccccc}
\hline \multirow{2}{*}{ Fatty Acid } & \multicolumn{7}{c}{ Tanzania } & & \\
\cline { 2 - 6 } & DAR & ARS & IRINGA & DOM & MOR & KGR \\
\hline Palmitic & 8.8 & 2.3 & 3.1 & 2.4 & 3.1 & 4.2 \\
Stearic & 2.9 & 4.2 & 1.1 & 1.4 & 1.1 & 1.8 \\
Oleic & 1.8 & 5.1 & 1.4 & 4.1 & 2.2 & 2.8 \\
Linoleic & 2.9 & 4.8 & 1.9 & 4.3 & 3.3 & 4.4 \\
Linolenic & T.A & T.A & T.A & T.A & T.A & T.A \\
Ricinoleic & 83.5 & 83.6 & 92.3 & 87.8 & 90.6 & 86.7 \\
SFA & 11.7 & 6.5 & 4.3 & 3.8 & 4.2 & 6.0 \\
UFA & 88.3 & 93.5 & 95.7 & 96.2 & 95.8 & 93.9 \\
\hline
\end{tabular}

CO from heavy motor vehicle trafficking in the city which subsequently results in acid rain. This acidity does not favour the uptake of nutrients which are required by the plants for the biosynthesis of various metabolites which include fatty acids and glycerols. Dar es Salaam has a very high humidity which also does not favour the biosynthesis of various fatty acids in the castor oil.

The GC-MS results shown in Table 1 revealed that the unsaturated fatty acids (UFA) composition was between $88.3 \%$ - 96.2\% and saturated fatty acid (sfa) ranged between $11.7 \%$ and 3.8\%. Ricinoleic acid was higher $(83.5 \%-92.3 \%)$ than other fatty acids in the castor oil and compares well with literature [19]. Based on the appended GC-MS chromatogram, some variations in fatty acid composition were observed in all six oil samples. The oil sample from Dar es Salaam showed the lowest percentage of ricinoleic acid and highest amounts of palmitic and stearic acids saturated fatty acids. This observation was also supported by the lowest iodine value which indicated the lowest degree of unsaturation. Probably for Dar es Salaam castor plants either the enzyme system controlling the formation of ricinoleic acid is absent in the early period of growth or it is present in some latent (inactive) form that is activated at a later stage [20]. Ricinoleic acid is largely formed in the last stages of growth where the delay in activation or formation of enzymes, the oil would largely remain with high SFA. This may explain why Dar es Salaam recorded highest percentage of palmitic acid and low ricinoleic acid. For other regions, the amount of palmitic acid compares with those reported in literature [21].

\subsection{Chemical Properties}

\subsubsection{Acid Value}

Except for Kagera region, the acid values obtained from different regions compares well with literature [10] [22]. Kagera had the highest acid value of $1.97 \mathrm{mg} / \mathrm{g}$ oil, presumably because of the hydrolysis that had taken place before its extraction. It was linked to this, because the seeds were collected from the ground where they had spent time and thus the action of lipase enzyme probably had already hydrolysed the triglycerides into free 
Table 2. Chemical parameters of Tanzanian castor oil.

\begin{tabular}{cccccc}
\hline Region & A.V (mg/g) & \% FFA & $\begin{array}{c}\text { P.V } \\
(\mathbf{m e q} / \mathbf{g})\end{array}$ & $\begin{array}{c}\text { S.V } \\
(\mathbf{m g ~ K O H} / \mathbf{g} \text { Oil })\end{array}$ & I.V (g/100 g Oil) \\
\hline Dar & 0.56 & 0.28 & 12.50 & 178.12 & 78.15 \\
Arusha & 0.51 & 0.26 & 13.73 & 171.54 & 80.20 \\
Iringa & 0.44 & 0.22 & 10.87 & 173.22 & 81.09 \\
Moro & 0.79 & 0.40 & 11.09 & 187.46 & 81.21 \\
Dodoma & 0.56 & 0.28 & 10.98 & 168.02 & 83.42 \\
Kagera & 1.97 & 0.99 & 10.79 & 165.50 & 80.61 \\
\hline
\end{tabular}

fatty acid and hence elevating the acid value. Iringa had the lowest acid value $(0.44 \mathrm{mg} / \mathrm{g}$ oil $)$, which is attributed to the low temperature in Iringa and probably due to the presence of strong phenolic anti-oxidants such as Butylated Hydroxyanisole (BHA) and Butylated Hydroxytoluene (BHT) [23]. Iringa has a very low temperature ranging from $15^{\circ} \mathrm{C}-25^{\circ} \mathrm{C}$ which in one way or another prevents the thermal dissociation of fatty acids in the oil. Generally, the values indicated the low level of hydrolysis by lipase in the oil had occurred, since the parameter was determined immediately after solvent extraction had completed. These values are small as compared to literature [24] but falls within the ASTM specifications shown in Table 4.

\subsubsection{The Peroxide Value}

The low levels of peroxide value obtained in this work, suggest either the presence of strong antioxidant that prevent the activity of oxygen that would otherwise spoil the oils. From Table 2, it is obvious that the P.V for the castor oil from Arusha and Dar es Salaam had high values compared to other regions and literature [8] although they are below values reported in the literature [25].

\subsubsection{Saponification Value}

High saponification value means low molecular weight of the triglyceride and the lower the SV, the higher the molecular weight. From Table 2, it was shown that Morogoro recorded highest saponification value while Kagera had the lowest saponification value. The values are characteristic of castor oil and the variations noticed were just due to little disparities in the fatty acid composition. The data compares well with some literatures [10] but lower as compared to ASTM values and other researchers [22].

\subsubsection{Iodine Value}

The result obtained for the Iodine value for different oils are shown in Table 2. They were low compared to the literature values suggested by the ASTM. This was probably because of the presence of more saturated fatty acids in the castor oil which did not absorb the Hanus iodine solution. Higher values show increase in the average degree of unsaturation of the oil, as such, the amount of iodine which can be absorbed by unsaturated acids would be higher. But as a result of their agreement with standards, all the oils could be classified as non-drying oils; since their iodine values were lower than 100 ( $\mathrm{g} \mathrm{I}_{2} / 100 \mathrm{~g}$ sample).

\subsection{Physical Properties}

\subsubsection{Refractive Index}

Table 3 shows that refractive index of castor oil in different regions varied between $1.468-1.473$ which was concurrent to the previous researchers [10] [18]. Slight differences between studies may be due to differences in study condition, planting and harvesting conditions [10]. Iringa had the highest refractive index while Dar es Salaam recorded a low refractive index. Probably, presence of impurities such as gums, phosphates in the oil was attributed to refractive index changes. Furthermore, Table 4 suggests the refractive index range that is above our results. In general, the higher the refractive index the greater the degree of unsaturation or conjugation and vice versa.

\subsubsection{Specific Gravity}

In Table 3, the specific gravity of the castor oils from different regions ranged from $0.945-0.954$ and they were 
Table 3. Physical parameters of Tanzanian castor oil.

\begin{tabular}{ccccc}
\hline Region & S.G & R.I & Viscosity (dPaS) & pH \\
\hline Arusha & 0.954 & 1.471 & 9.0 & 6.3 \\
Dodoma & 0.945 & 1.469 & 9.2 & 6.1 \\
Dar & 0.948 & 1.468 & 9.2 & 6.0 \\
Morogoro & 0.945 & 1.469 & 9.2 & 6.0 \\
Iringa & 0.943 & 1.473 & 9.3 & 5.8 \\
Kagera & 0.949 & 1.470 & 9.1 & 5.7 \\
\hline
\end{tabular}

\begin{tabular}{|c|c|}
\hline Property & Ranges \\
\hline Specific gravity $20 / 25^{\circ} \mathrm{C}$ & $0.957-0.968$ \\
\hline Refractive Index, $\mathrm{n}_{\mathrm{D}}$ & $1.476-1.479$ \\
\hline Viscosity at $25^{\circ} \mathrm{C}(\mathrm{St} / \mathrm{dPaS})$ & $9.3-10$ \\
\hline Iodine value & $82-88$ \\
\hline Saponification value & $175-187$ \\
\hline Free fatty acid & $0.3-0.7$ \\
\hline Acid value & $0.4-4.0$ \\
\hline
\end{tabular}

below the ASTM standards given in Table 4. This can be attributed to the presence of impurities and the use of non-standardized density bottle. The specific gravity of a substance will distinguish various oils and hence is an indicator of where a compound can be found in water in case of a spill.

\subsubsection{Viscosity}

The viscosity values obtained in this study (Table 4) showed slight variation between regions. This suggests that the chemical composition of the castor oil from castor seeds collected from the regions does not differ to a large extent. Interestingly, the values were similar to those reported elsewhere [10] [26].

\subsection{4. $\mathrm{pH}$}

Due to presence of free fatty acids in the castor oil, it was necessary to determine the $\mathrm{pH}$ of the oil since it tells the state of oil as to whether the dissociation has taken place or not. The $\mathrm{pH}$ of castor oils is summarized in Table 3. As seen in the table, castor oil from Kagera had the highest $\mathrm{pH}$ as compared to other regions. This is linked to the higher free fatty acids which are justified by its acid value and \% FFA.

\section{Conclusion}

This research has established that the amount of oil extracted from castor seeds collected from six regions in Tanzania varies. For solvent extraction (Soxhlet using $n$-hexane), we establish that the yield of castor oil ranges from $43 \%$ to $53 \%$ depending on the origin and variety of castor seeds. The physico-chemical parameters of the castor oil are determined using standard methods and most of them are within the ASTM values and those reported elsewhere. The fatty acid profile of the castor oils reveals some disparities in the amount of fatty acids suggesting that there can be climatic and soil composition influences on the fatty acid profiles. The results show that seeds from Dodoma have the highest oil possibly due to the type of soil and the climate. The region receives a minimal amount of rainfall and has a favorable ambient temperatures ranging from $28^{\circ} \mathrm{C}$ to $34^{\circ} \mathrm{C}$ with very low humidity.

\section{Acknowledgements}

We would like to acknowledge Southern Africa Biochemistry and informatics of Natural products (SABINA) 
for partial financial support to this work. The University of Dar es Salaam Chemistry department staffs are acknowledged for their skillful technical assistance.

\section{References}

[1] Bello, E.I. and Makanju, A. (2011) Production Characterization and Evaluation of Castor Oil Biodiesel as Alternative Fuel for Diesel Engines. Journal of Emerging Trends in Engineering and Applied Science, 2, 525-530.

[2] Nielsen, F., Hill, B. and Jongh, J. (2011) FACT Arrakis FACT Project No. 146/W/W/001, Castor (Ricinus cummunis): Potential of Castor for Bio-Fuel Production. 2nd Edition. www.factfoundation.com

[3] Mutlu, H. and Meier, M.A.R. (2010) Castor Oil as a Renewable Resource for the Chemical Industry. European Journal of Lipid Science and Technology, 112, 10-30. http://dx.doi.org/10.1002/ejlt.200900138

[4] Alizeralu, A.F.N., Shirzad, H. and Harzati, S. (2011) The Effect of Climatic Factors on the Production and Quality of Castor Oil. Natural Science, 9, 15-19.

[5] Okullo, A., Temu, A.K., Oguwok, P. and Ntalikwa, J.W. (2012) Physico-Chemical Properties of Biodiesel from Jatropha and Castor Oils. International Journal of Renewable. Energy Research, 2, 47-56.

[6] Ogoniyi, D.S. (2006) Castor Oil: A Vital Industrial Raw Material. Bioresource Technology, 97, 1086-1091. http://dx.doi.org/10.1016/j.biortech.2005.03.028

[7] Salimon, J., Noor, D.A.M., Nazrizawati, A.T., Firdaus, M.Y.M. and Noraishah, A. (2010) Fatty Acid Composition and Physicochemical Properties of Malaysian Castor Bean (Ricinus communis) Seed Oil. Sains Malaysiana, 39, 761-764.

[8] Abigotun, A., Alademeyin, O. and Oloye, D. (2009) Extraction and Characterization of Castor Seed Oil. Internet Journal of Nutrition and Wellness, 8, 1-3.

[9] Isah, A.G. (2006) Production of Detergent from Castor Oil. Leonardo Electronic Journal of Practices and Technologies, 9, 153-160.

[10] Weatherbase (2011) Weatherbase: Historical Weather for Arusha, Dar es Salaam, Dodoma, Iringa, Kagera and Morogoro Tanzania.

[11] Schneider, R.C.S., Baldissarelli, V.Z., Trombetta, F., Mrtinelli, M. and Caramao, E.B. (2004) Optimization of Gas Chromatographic-Mass Spectrometric Analysis for Fatty Acids in Hydrogenated Castor Oil Obtained by Catalytic Transfer Hydrogenation. Analytica Chimica Acta, 505, 223-226. http://dx.doi.org/10.1016/j.aca.2003.10.070

[12] McMaster, M.C. (2008) GC-MS: A Practical User’s Guide. 2nd Edition, John Wiley and Sons, Inc., Hoboken. http://dx.doi.org/10.1002/9780470228357

[13] Auta, M. (2013) Extraction and Characterization of Drilling Oil from Castor Oil. International Journal of Innovation and Applied Studies, 3, 382-387.

[14] Warra, A.A., Wawata, I.G., Gunu, S.Y. and Aujara, K.M. (2011) Extraction and Physicochemical Analysis of Some Selected Northern Nigerian Industrial Oils. Archives of Applied Science Research, 3, 536-554.

[15] Kyari, M.Z. (2008) Extraction and Characterization of Seed Oils. International Agrophysics, 22, 139-142.

[16] AL-Hamdany, A.J. and Jihad, T.W. (2012) Oxidation of Some Primary and Secondary Alcohols Using Pyridinium Chlorochromate. Tikrit Journal of Pure Science, 17, 72-76.

[17] James, A.T., Hadaway, H.C. and Joan, P.W.W. (1965) The Biosynthesis of Ricinoleic Acid. Biochemical Journal, 95, 448-452. http://dx.doi.org/10.1042/bj0950448

[18] Akpan, U.G., Jimoh, A. and Mohammed, A.D. (2006) Extraction Characterization and Modification of Castor Seed Oil. Leonardo Journal of Sciences, 8, 43-52.

[19] Shrirame, H.Y., Panwar, N.L. and Bamniya, B.R. (2011) Bio Diesel from Castor Oil—A Green Energy Option. Low Carbon Economy, 2, 1-6. http://dx.doi.org/10.4236/lce.2011.21001

[20] Shridhar, B.S., Beena, K.V., Anita, M.V. and Paramjeet, K.B. (2010) Optimization and Characterization of Castor Seed Oil. Leonardo Journal of Sciences, 17, 59-70.

[21] Aluyor, E.O. and Ori-Jesu, M. (2008) The Use of Antioxidants in Vegetable Oils-A Review. African Journal of Biotechnology, 7, 4836-4842.

[22] Saribiyik, O.Y., Ozcanli, M., Serin, H., Serin, S. and Aydin, K. (2010) Biodiesel Production from Ricinus communis Oil and Its Blends with Soybean Biodiesel. Journal of Mechanical Engineering, 56, 811-816.

[23] Oliniyan, A.M. (2010) Effect of Extraction Conditions on the Yield and Quality of Oil from Castor Bean. Journal of Cereals and Oilseeds, 1, 24-33.

[24] Muzenda, F., Kabuba, J., Mdletye, P. and Belaid, M. (2012) Optimization of Process Parameters for Castor Oil Production. Proceedings of the World Congress on Engineering 2012, Vol. III, London, 4-6 July 2012, 1586-1589. 
[25] Udiandeye, J.A., Okewale, A.O., Etuk, B.R. and Igbokwe, P.K. (2011) Investigation on the Use of Castor Seed Oil and Rubber Seed Oil as Corrosion Inhibitors. International Journal of Basic and Applied Sciences, 11, 48-54.

[26] Bello, E.I., Mogaji, T.S. and Makanju, A. (2011) The Effects of Transesterification on Selected Fuel Properties of Three Vegetable Oils. Journal of Mechanical Engineering Research, 3, 218-225. 